\title{
The Light Response of ON Bipolar Neurons Requires $\mathbf{G} \alpha_{\mathrm{o}}$
}

\author{
Anuradha Dhingra, ${ }^{1}$ Arkady Lyubarsky, ${ }^{2}$ Meisheng Jiang, ${ }^{3}$ Edward N. Pugh Jr, ${ }^{2}$ Lutz Birnbaumer, ${ }^{3}$ \\ Peter Sterling, ${ }^{1}$ and Noga Vardi ${ }^{1}$

\begin{abstract}
Departments of ${ }^{1}$ Neuroscience and ${ }^{2}$ Ophthalmology, University of Pennsylvania, Philadelphia, Pennsylvania 19104, and
\end{abstract} \\ ${ }^{3}$ Department of Anesthesiology, University of California at Los Angeles, Los Angeles, California 90024
}

\begin{abstract}
ON bipolar neurons in retina detect the glutamate released by rods and cones via metabotropic glutamate receptor 6 (mGluR6), whose cascade is unknown. The trimeric $G$-protein $G_{0}$ might mediate this cascade because it colocalizes with mGluR6. To test this, we studied the retina in mice negative for the $\alpha$ subunit of $\mathrm{G}_{\mathrm{o}}\left(\mathrm{G} \alpha_{\mathrm{o}}-/-\right)$. Retinal layering, key cell types, synaptic structure, and mGluR6 expression were all normal, as was the a-wave of the electroretinogram, which represents the rod and cone photocurrents. However, the b-wave of the electroretinogram,
\end{abstract}

both rod- and cone-driven components, was entirely missing. Because the b-wave represents the massed response of ON bipolar cells, its loss in the $\mathrm{G} \alpha$ o null mouse establishes that the light response of the $\mathrm{ON}$ bipolar cell requires $\mathrm{G}_{\mathrm{o}}$. This represents the first function to be defined in vivo for the $\alpha$ subunit of the most abundant G-protein of the brain .

Key words: G-protein; mGluR6; metabotropic glutamate receptor; retina; bipolar cells; electroretinogram; rod bipolar cells; second messenger cascade
ON bipolar neurons comprise three-quarters of all bipolar cells in mammalian retina, including all rod bipolar and one-half of the cone bipolar cells (Sterling et al., 1988; Cohen and Sterling, 1990; Martin and Grünert, 1992; Strettoi and Masland, 1995). These neurons detect glutamate released by rods and cones by means of metabotropic glutamate receptor 6 (mGluR6) (Nakajima et al., 1993; Nomura et al., 1994). Initially, mGluR6 was thought to trigger a cascade resembling that for phototransduction (Nawy and Jahr, 1990; Shiells and Falk, 1990). However, the main components of the phototransduction cascade (transducin, phosphodiesterase, and a cGMP-gated cation channel) were not found in the ON bipolar dendrites (Wässle et al., 1992; Vardi et al., 1993). Instead, a different trimeric G-protein was found: $G_{0}$ (Vardi et al., 1993; Vardi, 1998).

$\mathrm{G}_{\mathrm{o}}$ has been suggested as the second step in the $\mathrm{ON}$ bipolar cascade because of the following: (1) it colocalizes with mGluR6 in the dendrites (Vardi, 1998; Vardi et al., 2000); (2) agonist-bound mGluR6 can activate its $\alpha$ subunit $\left(\mathrm{G} \alpha_{\mathrm{o}}\right)$ in vitro (Weng et al., 1998); and (3) $\mathrm{G} \alpha_{\mathrm{o}}$ dialyzed into ON bipolar cells reduces the response to glutamate (Nawy, 1999). However, doubt persists regarding the role of $G_{o}$ because, rather than coupling mGluR6 to the effector, it might merely modulate the cascade, e.g., by affecting channel phosphorylation. If $\mathrm{G}_{\mathrm{o}}$ merely modulates the cascade, a retina lacking $\mathrm{G} \alpha_{\mathrm{o}}$ might have an altered $\mathrm{ON}$ response (Greif et al., 2000), but if $\mathrm{G} \alpha_{\mathrm{o}}$ actually couples mGluR6 to an effector, a null retina would have no $\mathrm{ON}$ response. Here we show that the retina in a $\mathrm{G} \alpha_{\mathrm{o}}-1-$ mouse appears normal, but the ON response to rod and cone stimuli, as measured by the b-wave of an electroretinogram (ERG), is completely absent.

\section{MATERIALS AND METHODS}

Mice null for $\mathrm{G} \alpha_{\mathrm{o}}$ (both splice variants) rarely reach adulthood (Valenzuela et al., 1997; Jiang et al., 1998), so the colony was maintained by breeding heterozygotes. Heterozygous animals were received from the late Eva J. Neer (Harvard Medical School, Boston, MA). All experiments

Received July 21, 2000; revised Sept. 27, 2000; accepted Oct. 3, 2000.

This work was supported by National Eye Institute Grants EY11105, EY00828, EY02660, and DK19318. We thank Eva Neer for providing us with the initial pairs of $\mathrm{G} \alpha_{\mathrm{o}}+/-$ mice; Dave Manning, Alexander Dizhoor, and Shigetada Nakanishi for providing antibodies; Yi-Jun Shi, Sally Shrom, and Jian Li for technical assistance; and Sharron Fina for preparing this manuscript.

Correspondence should be addressed to Dr. Noga Vardi, Department of Neuroscience, University of Pennsylvania, Philadelphia, PA 19104. E-mail: noga@retina.anatomy. upenn.edu.

Copyright (C) 2000 Society for Neuroscience $\quad 0270-6474 / 00 / 209053-06 \$ 15.00 / 0$ involving animals were done in compliance with federal regulations and University of Pennsylvania policy.

Genotyping. The tip of a mouse tail $(0.5 \mathrm{~cm})$ was incubated in lysis buffer containing $100 \mathrm{~mm}$ Tris- $\mathrm{HCl}, \mathrm{pH} 8.5,5 \mathrm{~mm}$ EDTA, 0.2\% SDS, $200 \mathrm{~mm}$ $\mathrm{NaCl}$, and $100 \mu \mathrm{g} / \mathrm{ml}$ proteinase $\mathrm{K}$ at $55^{\circ} \mathrm{C}$ overnight. After centrif ugation, the supernatant was decanted into $500 \mu \mathrm{l}$ of isopropanol to precipitate the DNA. PCR primers used to amplify $\mathrm{G} \alpha$ o were as follows: 5'-AGG GGA TGA GAG CCG CCT GCA GTC-3' and 5'-ATG ATG GCC GTG ACA TCC TCG AAG CA-3'. The neo gene was amplified using 5'-ACC TGG TCA TAG CCG CTG AGT-3' and 5'-TGC CGA GAA AGT ATC CAT CAT G-3' (Jiang et al., 1998). PCR conditions were as follows: an initial cycle at $96^{\circ} \mathrm{C}(3 \mathrm{~min}), 63^{\circ} \mathrm{C}(5 \mathrm{~min})$, and $72^{\circ} \mathrm{C}(45 \mathrm{sec})$; then 30 cycles at $94^{\circ} \mathrm{C}$ $(30 \mathrm{sec}), 63^{\circ} \mathrm{C}(30 \mathrm{sec})$, and $72^{\circ} \mathrm{C}(45 \mathrm{sec})$; and a final hold at $72^{\circ} \mathrm{C}(5 \mathrm{~min})$.

Electroretinographic recordings. The experimental apparatus, methods of light stimulation and quantification, ERG recording, and cone signal isolation have been described in detail previously (Lyubarsky et al., 1999). Briefly, a mouse was dark-adapted for $2 \mathrm{hr}$; then, under dim red light, it was deeply anesthetized by injecting intraperitoneally ketamine $(20 \mu \mathrm{g} / \mathrm{gm})$ plus xylazine $(8 \mu \mathrm{g} / \mathrm{gm})$. The animal was immobilized in a holder with the right eye pointing upward; then the pupil was dilated with $1 \%$ tropicamide, and the eye was protected with a drop of methylcellulose. A platinum recording electrode contacted the cornea, and a tungsten reference electrode was inserted subcutaneously on the forehead. The animal in its holder was then placed inside a light-proof Faraday cage, and light stimuli were delivered through several ports. Light stimuli were $1 \mathrm{msec}$ flashes generated with xenon flash tubes. The intensity and spectral composition were controlled with neutral density and bandpass interference filters. Light intensities were calibrated and converted to estimated number of photoisomerization per photoreceptor $\left(R^{*}\right)$ as described previously (Lyubarsky et al., 1999). For dim flashes, 10- 40 responses were averaged for each experimental condition; for intense flashes, two to five responses were averaged.

Immunocytochemistry. Eyes were enucleated from an anesthetized mouse $(85 \mu \mathrm{g} / \mathrm{gm}$ ketamine and $13 \mu \mathrm{g} / \mathrm{gm}$ xylazine $)$, and the animal was killed by anesthetic overdose. A small cut was made through the lens, after which the eyeball was immersion-fixed in $4 \%$ paraformaldehyde plus $0.01 \%$ glutaraldehyde buffered at $\mathrm{pH} 7.3$ [room temperature (RT), $1 \mathrm{hr}$ ]. The eye was then rinsed in buffer, soaked overnight in $30 \%$ buffered sucrose, embedded in a mixture of $20 \%$ buffered sucrose and tissue freezing medium (2:1), and cryosectioned at $10 \mu \mathrm{m}$. Sections were soaked in $0.1 \mathrm{M}$ phosphate buffer containing $10 \%$ normal goat serum, $5 \%$ sucrose, and $0.3 \%$ Triton X-100 (diluent) (RT, $1 \mathrm{hr}$ ), incubated in primary antibody (in diluent) $\left(4^{\circ} \mathrm{C}\right.$, overnight), washed and incubated in secondary antibody conjugated to a fluorescent marker ( $3 \mathrm{hr}$ ) (Jackson ImmunoResearch, West Grove, PA), and mounted in Vectashield (Vector Laboratories, Burlingame, CA). Digital images were acquired by a confocal microscope (Leica, Exton, PA). Images were cropped, enlarged, and contrastenhanced with Adobe Photoshop (Adobe Systems, San Jose, CA). Final resolution was $\sim 300$ dots per inch.

Antibodies. Two antibodies for $\mathrm{G}_{\alpha_{\mathrm{o}}}$ were used: rabbit polyclonal directed against the specific peptide ANNLRGCGLY located at the C terminus of the $\alpha$ subunit (gift from Dr. D. Manning, University of Pennsylvania, Philadelphia, PA) (Carlson et al., 1989; Law et al., 1991; Vardi et al., 1993) and a mouse monoclonal against the purified bovine protein (MAB 3071; Chemicon, Temecula, CA) (Li et al., 1995). Anti-mGluR6 was directed 
A

Figure 1. Null retina has normal thickness. $A$, One micrometer radial Epon sections (stained with toluidine blue) show that all the layers in the $\mathrm{G} \alpha_{\mathrm{o}}-/-$ retina are present at normal morphology (6 postnatal weeks). $B$, Measurements of individual retinal layers show no difference between wild type and null ( 2 retinas at $\sim 4$ postnatal weeks and 2 at 6 postnatal weeks; measured from Epon sections). $O S$, Outer segment; $I S$, inner segment; $O N L$, outer nuclear layer; $O P L$, outer plexiform layer; $I N L$, inner nuclear layer; $I P L$, inner plexiform layer; $G C L$, ganglion cell layer; $P R$, photoreceptor outer and inner segments; $W R$, whole retina.
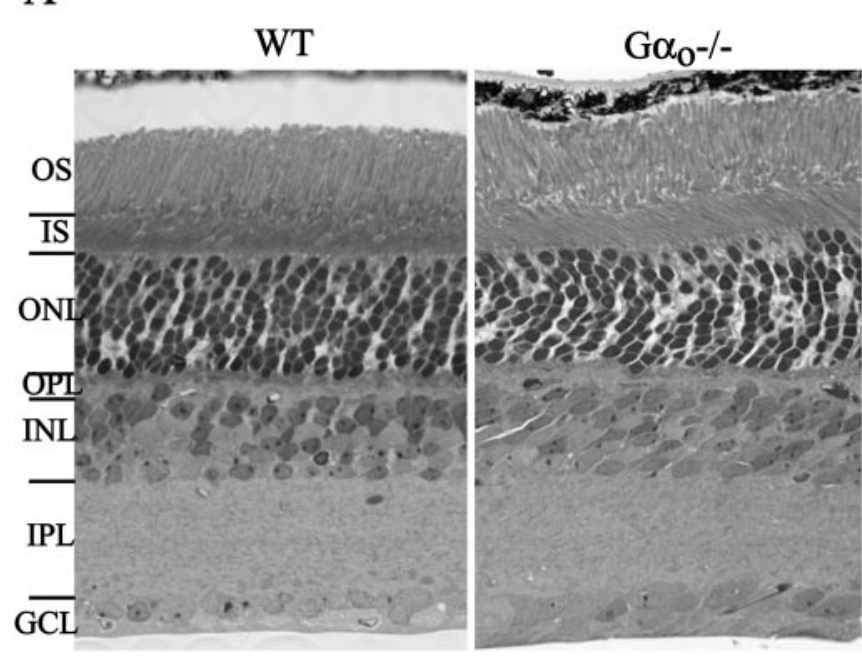

B

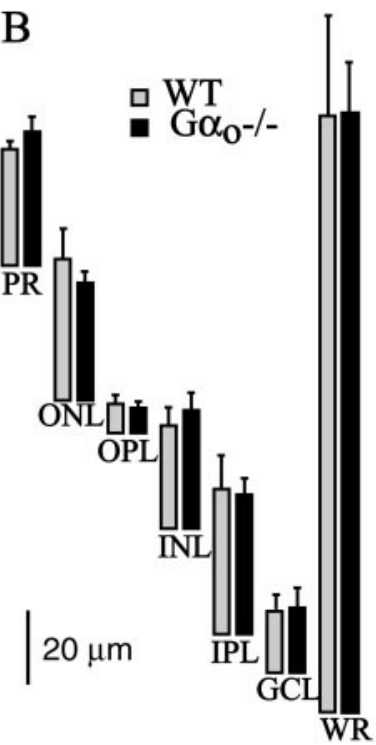

against the $\mathrm{C}$ terminus of rat mGluR6 (gift from Dr. S. Nakanishi, Kyoto University, Kyoto, Japan). Anti-recoverin was directed against bovine recoverin (gift from Dr. A. M. Dizhoor, University of Washington, Seattle, WA). Anti-calbindin D28 was a rabbit polyclonal (Swant, Bellinzona, Switzerland), and anti-protein kinase C (PKC) was a mouse monoclonal (Sigma, St. Louis, MO and Amersham Pharmacia Biotech, Little Chalfont, UK).

Electron microscopy. Eyes were fixed in phosphate buffer $(0.12 \mathrm{M}, \mathrm{pH} 7.3)$ containing 2\% glutaraldehyde, $2 \%$ paraformaldehyde, and 5\% glucose. Eyes were rinsed in phosphate buffer, and then a small piece of retina was taken $\left(\sim 1 \times 1 \mathrm{~mm}^{2}\right.$, with the optic disk in the center). Tissue was osmicated $(1 \%, 1 \mathrm{hr})$, partially dehydrated in $50 \%$ and $70 \%$ ethanol, stained en bloc in $1 \%$ ethanolic uranyl acetate $(1 \mathrm{hr})$, dehydrated, and embedded in Epon. Ultrathin sections $(80-90 \mathrm{~nm})$ were counterstained with uranyl acetate and lead citrate and photographed in an electron microscope. Semi-thin sections $(1 \mu \mathrm{m})$ were stained with toluidine blue.

\section{RESULTS}

\section{$\mathbf{G} \alpha_{\mathrm{o}}-/-$ retina appears normal}

To test whether the absence of $\mathrm{G} \alpha_{\mathrm{o}}$ affects retinal development, we compared retinas from 3-8 postnatal week null mice with wild-type littermates. The null retinas were identical in thickness to wild-type retinas of the same age. Photoreceptors, including outer and inner

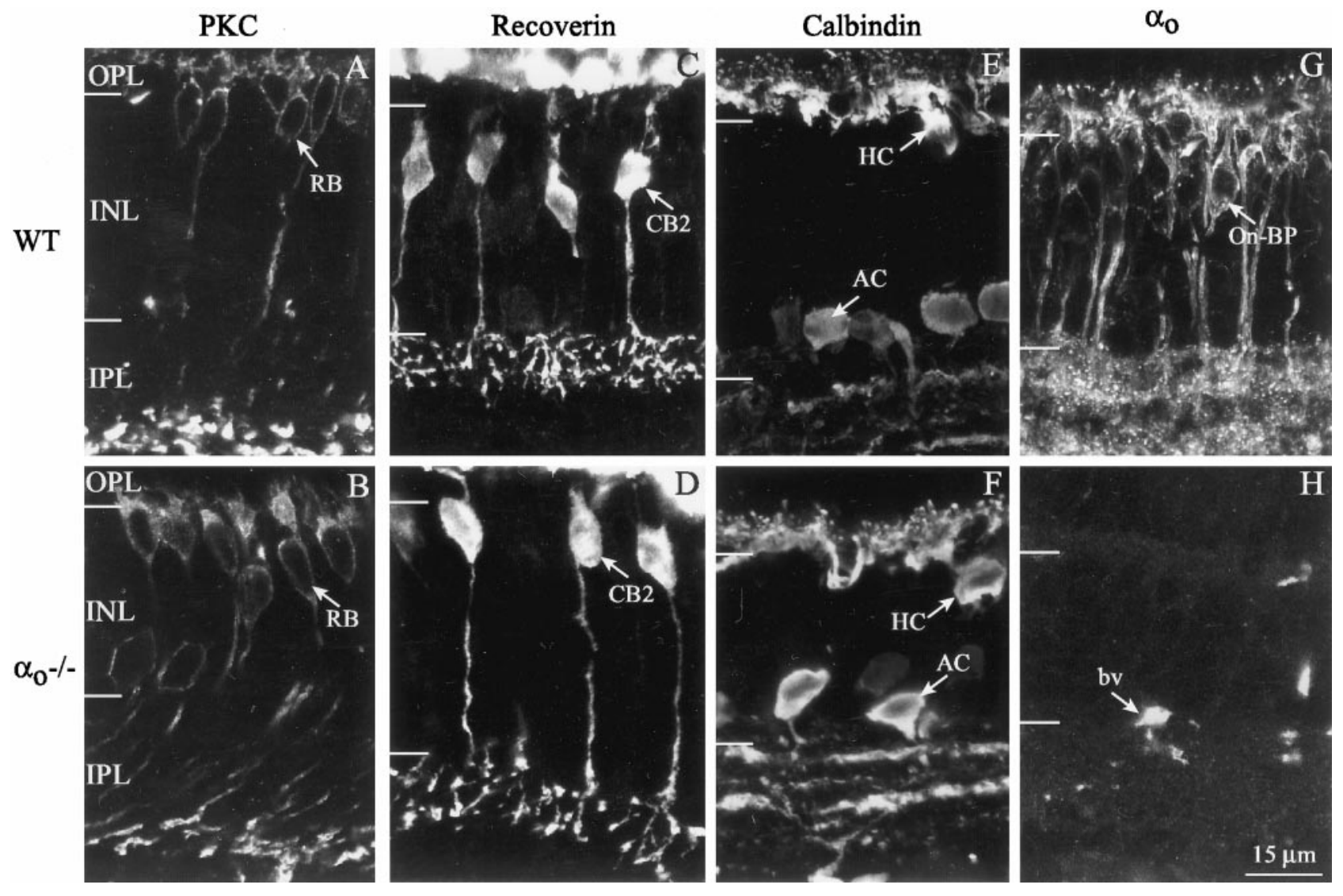

Figure 2. Specific cell types in the null retina express standard chemical markers and normal morphology (confocal images; 3 postnatal weeks). $A, B$, Rod bipolar cells $(R B)$ express PKC. $C, D$, OFF bipolar cells (probably type $\mathrm{CB} 2)$ express recoverin. $E$, $F$, Horizontal $(H C)$ and amacrine $(A C)$ cells express calbindin. $G, H$, Wild-type retina expresses $\mathrm{G} \alpha_{\mathrm{o}}$ in $\mathrm{ON}$ bipolar cells $(O n-B P)$ and IPL, but null retina does not. $b v$, Blood vessel. 
mGluR6
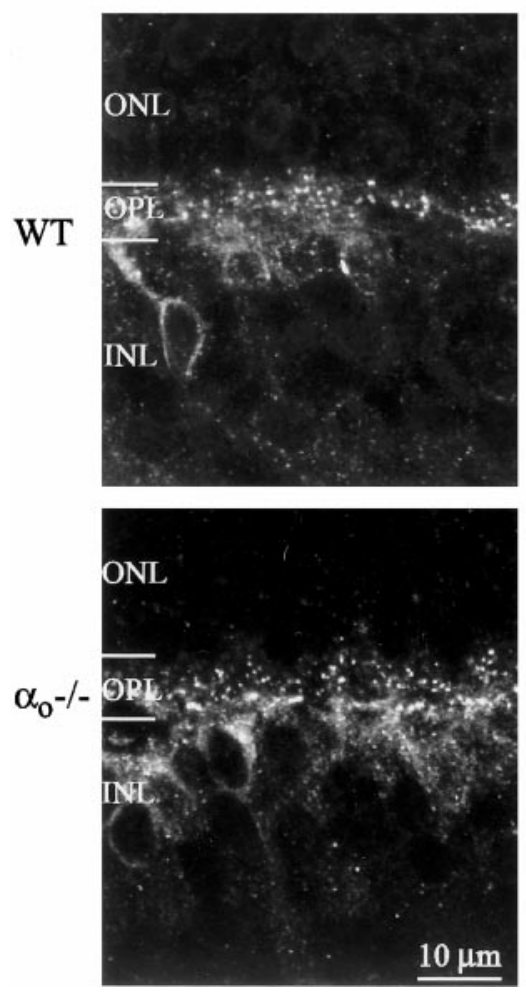
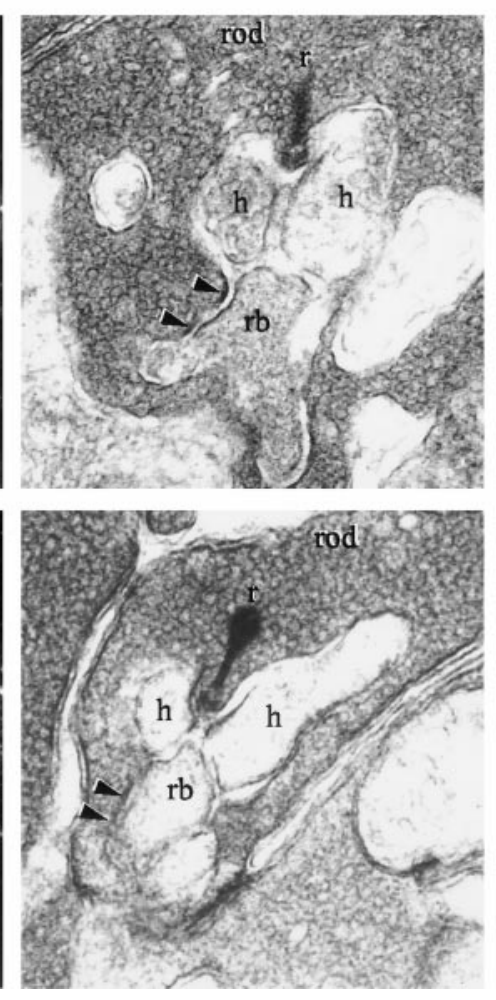

Photoreceptor synaptic complex
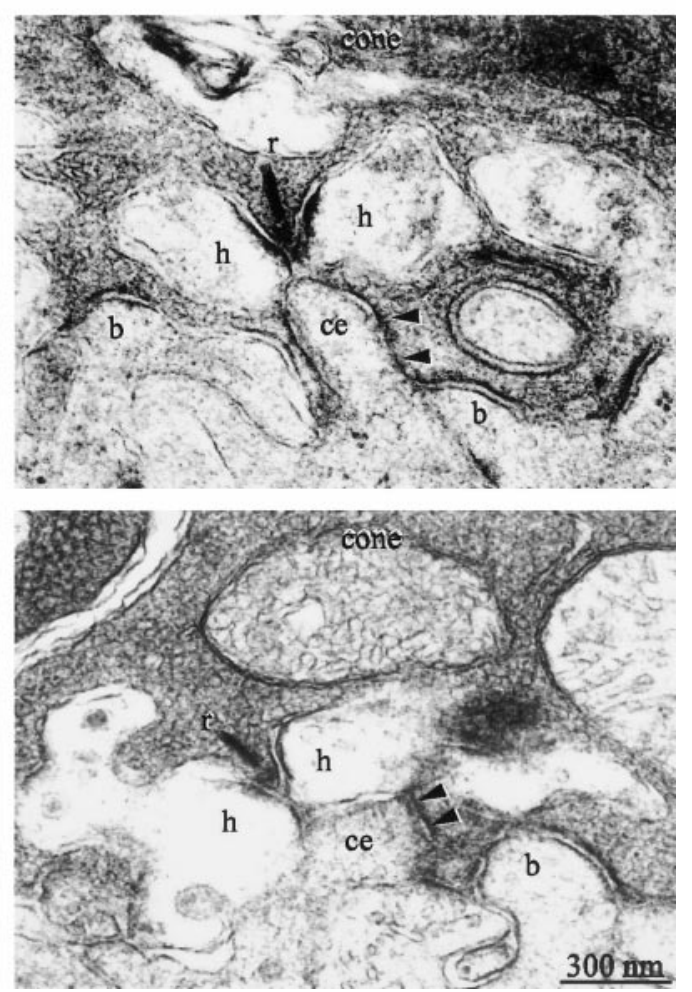

Figure 3. Synaptic apparatus of the null retina is normal. Left, Confocal image of immunostain for mGluR6. Stain concentrates in the outer plexiform layer in dendritic tips of ON bipolar cells and shows no difference between wild type and null (7 postnatal weeks). Middle, Electromicrographs of rod terminal. Right, Electromicrographs of cone terminals. Presynaptic elements: synaptic ribbon $(r)$, synaptic vesicles, and dense photoreceptor membrane (arrowheads) are intact in the null retina. Postsynaptic elements: appear at their normal positions, lateral for horizontal cell processes $(h)$, central for rod bipolar dendrite $(r b)$ and ON cone bipolar dendrite $(c e)$, and basal for OFF bipolar dendrites $(b)$.

segments, axon, soma, and terminal, appeared fully developed, and all layers were present at normal thickness (Fig. 1).

We probed the morphology of specific cell types by staining with established immunomarkers: anti-PKC for rod bipolar cells; antirecoverin for OFF cone bipolar cells; and anti-calbindin for horizontal and amacrine cells. These cell types were indistinguishable in null and wild-type retinas (Fig. 2). Thus, rod bipolar somas were positioned normally, high in the inner nuclear layer (INL), with dendrites arborizing in the outer plexiform layer (OPL) and axons arborizing in the deepest stratum of the inner plexiform layer (IPL) (Fig. 2A,B). The OFF cone bipolar cell stained for recoverin (probably CB2) (Euler and Wässle, 1995) arborized diff usely in the OFF sublamina of the IPL (Fig. 2C,D). Horizontal cell processes invaginated rod and cone terminals, and amacrine processes formed three sharp bands in the IPL (Fig. $2 E, F$ ). These experiments were performed on 3- and 7-week-old animals with same results.

Wild-type retinas already expressed $\mathrm{G} \alpha_{\mathrm{o}}$ by 3 postnatal weeks, showing the adult pattern (Fig. 2G). Thus, immunostain was present in bipolar somas high in the INL, in bipolar dendrites, and in the IPL. Null retinas were immunonegative for $\mathrm{G} \alpha_{\mathrm{o}}$ (Fig. 2H). In short, except for the absence of $\mathrm{G} \alpha_{\mathrm{o}}$, the null retina seemed completely normal.

\section{Photoreceptor synaptic complex appears normal}

Conceiveably, the absence of $\mathrm{G} \alpha_{\mathrm{o}}$ from the $\mathrm{ON}$ bipolar dendrite might affect the expression of mGluR6, or there might be transsynaptic effects on the structure of the rod and cone terminal. If so, a primary defect of bipolar cell transduction would not be distinguishable from such second-order effects. However, both null and wild-type retinas stained identically for mGluR6; puncta were stained in OPL and somas in the upper tiers of the INL (Fig. 3, left). Also, detailed examination by electron microscopy of the rod and cone terminals (tissue was examined in two wild types at 3.5 and 6 weeks old and two nulls at 4 and 6 weeks old) showed similar synaptic ribbons, synaptic vesicles, invaginating processes, "synaptic triad" (two horizontal cell processes flanking a central bipolar dendrite), electron-dense apposition between photoreceptor plasma membrane and bipolar dendrite, and "basal contact" between cone basal surface and bipolar dendrite (Fig. 3). Thus, in the null retina, all of the key ultrastructural features of the photoreceptor synaptic complex seemed normal.

\section{$\mathbf{G} \alpha_{\mathrm{o}}$ null mice lack the $\mathrm{b}$-wave of the electroretinogram but retain the a-wave}

Most of the components of the ERG can be recorded from a wild-type mouse 2 weeks postnatally, after which the ERG components rapidly reach mature proportions (see below). We recorded ERGs from postnatal day 21 (P21) to P60 mice.

A normal, dark-adapted mouse responds to a dim flash [510 nm; $\sim 20$ photoisomerizations $\left.\left(R^{*}\right) \operatorname{rod}^{-1}\right]$ with a "scotopic b-wave" $(100-200 \mu \mathrm{V})$, generated by the transduction current of the depolarizing rod bipolar cells (Robson and Frishman, 1995). We observed the scotopic b-wave in both wild-type and heterozygous mice. However, in $\mathrm{G} \alpha$ o null mice, the same flash evoked no b-wave (Figs. $4 A, 5 A$ ). Of course, the b-wave would fail if the rods were themselves impaired, so we examined rod function by stimulating dark-adapted mice with an intense white flash that isomerized $\sim 1 \%$ of the rhodopsin. This strong stimulus causes rapid closure of the cGMP-activated channels and completely suppresses the rod circulating current. Suppression of the circulating current produces an ERG field potential, the a-wave, of saturating amplitude (Hagins et al., 1970; Hood and Birch, 1993; Breton et al., 1994; Lyubarsky and Pugh, 1996; Pugh et al., 1998). The saturating a-wave amplitudes in the wild-type, heterozygous, and null mice were indistinguishable (Figs. $4 B, 5 B$ ). Thus, we conclude that the rods have normal cGMP-activated currents and normal phototransduction. Because rods are functional, the absence of the 


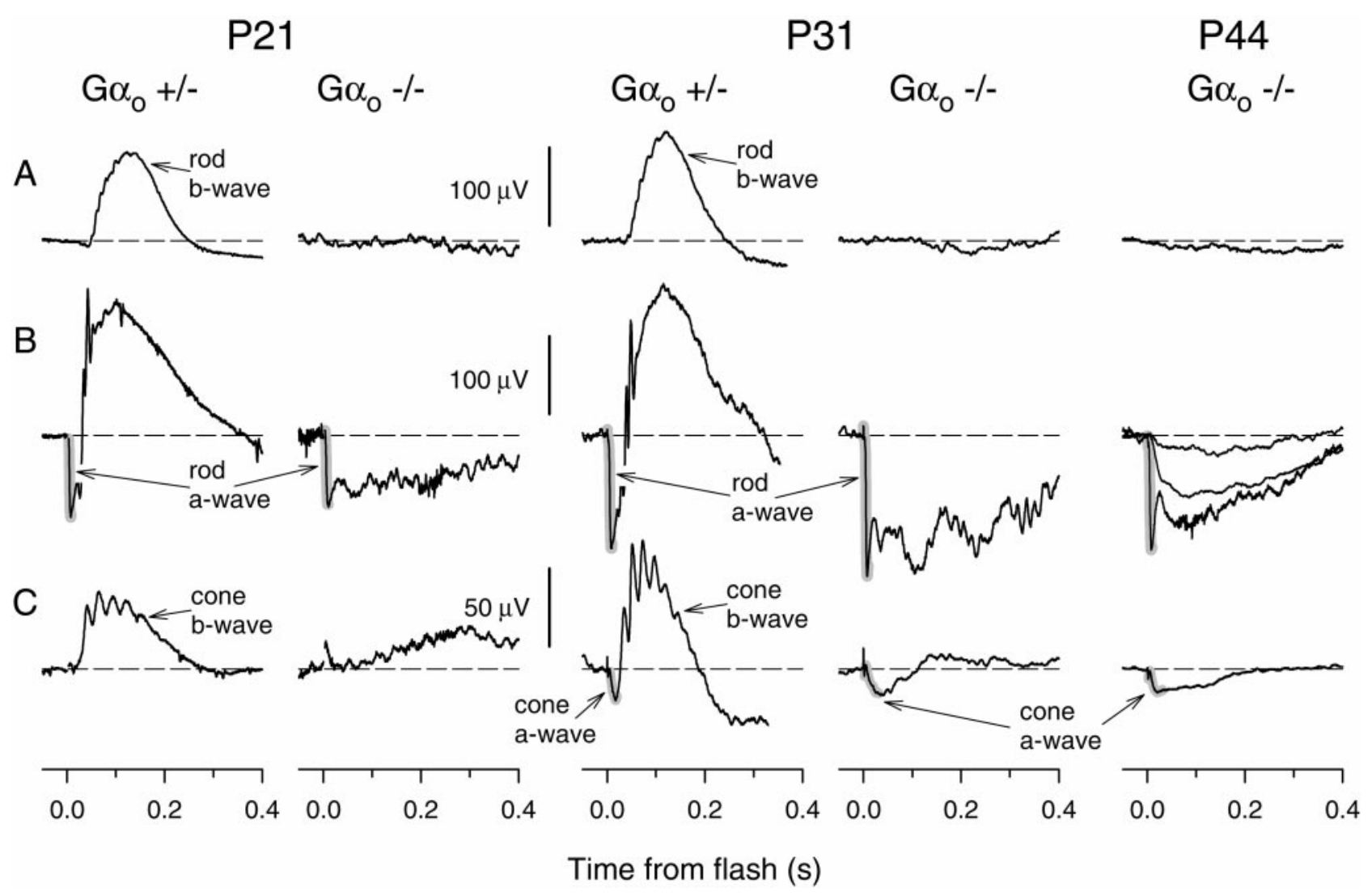

Figure 4. Rod- and cone-driven b-waves are absent from the electroretinogram of the null mouse. $A$, Animals dark-adapted for 2 hr were stimulated with dim flashes. Such flashes elicited a rod-driven, corneal-positive b-wave in the heterozygotes but no positive-going responses in the null mice. The estimated flash intensities in photoisomerizations per rod $(\Phi)$ and the number of responses $(n)$ averaged for each trace shown were as follows: for the P21 and P31 mice, $\Phi=20, n=11$; for the P44 mouse, $\Phi=3, n=40 . B$, Dark-adapted animals were stimulated with an intense flash (isomerizing $\sim 1 \%$ of the rhodopsin). This elicited in the heterozygote a negative a-wave (shading), followed by a positive-going b-wave. In the null mice, the a-wave was normal, but the b-wave was absent. The flash intensities $(\Phi)$ and the number of responses $(n)$ averaged were as follows: for the P21 and P31 mice, $\Phi=10^{6}, n=$ $2-4$. For the P44 mouse responses to three intensities are shown: $\Phi=20, n=20 ; \Phi=500, n=16 ; \Phi=10^{6}, n=2$. $C$, Mice were adapted to a bright background $\left(540 \mathrm{~nm} ; 20,000 R^{*} \operatorname{rod}^{-1} \mathrm{~s}^{-1}\right)$ that completely suppressed the cGMP-activated current of the rods. They were then stimulated with an intense white flash that isomerizes $\sim 1 \%$ of the M-cone pigment and $0.1 \%$ of the UV-cone pigment in adult mice. The cone-driven a-wave was not visible in the P21 animals but was pronounced in P31 and P44 animals (both $\mathrm{G} \alpha_{\mathrm{o}}+/-$ and $\mathrm{G} \alpha_{\mathrm{o}}-/-$ ). A typical cone-driven b-wave (positive-going response with superimposed oscillations, peaking $\sim 70-90 \mathrm{msec}$ after the flash) was observed in the $\mathrm{G} \alpha_{\mathrm{o}}+/-$ mice of all age groups but was absent in the $\mathrm{G} \alpha_{\mathrm{o}}-/-\mathrm{mice}$. For P21 and P31 G $\alpha_{\mathrm{o}}+/-$ mice, $n=10$; for P21 G $\alpha_{\mathrm{o}}-/-, n=20$; for P31 and P44 G $\alpha_{\mathrm{o}}-/-, n=40$. The slow positive-going potential in P21 mouse is probably an artifact attributable to movement of the lightly anesthetized mouse.

b-wave in the null mice in response to both the dim and bright flashes indicates failure of signal transduction in the rod bipolar cell.

Mouse retina contains a substantial population of ON bipolar cells driven by cones (Jeon et al., 1998). Because dendrites of these cells express $G_{o}$, it was of interest to examine cone-driven responses. To isolate the cone-driven components of the ERG, we presented a bright steady background $\left(540 \mathrm{~nm} ; \sim 20,000 R^{*} \operatorname{rod}^{-1}\right.$ $\left.\mathrm{S}^{-1}\right)$, which completely suppresses the rod circulating current and permits measurement of purely cone-driven a- and b-waves (Pugh et al., 1998; Lyubarsky et al., 1999, 2000). The wild-type and heterozygous mice exhibited robust cone b-waves, but the null showed no reliable positive-going responses (Figs. 4C, 5C). All mice groups showed normal cone a-waves (Figs. $4 C, 5 D$ ). Previous work has attributed the cone a-wave mostly to the suppression of the cone circulating current; however, it may also contain a component contributed by the activation of cone-driven OFF bipolar cells.

Because the $\mathrm{G} \alpha_{\mathrm{o}}-/-$ mice have a low survival rate, we took most of our data points from the early age of 21-30 d. However, to test whether the lack of a b-wave might be attributable to a lag in development, we also tested older mice of up to $60 \mathrm{~d}$. In the wild type, all of the ERG components grew rapidly between P21 and $\mathrm{P} 25$. In the null mouse, the rod- and cone-driven a-waves were similar to those of the wild type, but the b-waves were always missing (Fig. 5).

\section{DISCUSSION}

\section{$\mathbf{G} \alpha_{\mathrm{o}}$ is necessary for the $\mathrm{ON}$ bipolar response}

A mouse lacking the $\alpha$ subunit of $\mathrm{G}_{\mathrm{o}}$ fails to produce either a scotopic or a photopic b-wave. The b-wave is elicited when the glutamate release from a photoreceptor is suppressed by light increment (Pugh et al., 1998; Green and Kapousta-Bruneau, 1999; Robson and Frishman, 1999; Shiells and Falk, 1999). This opens cation channels in the ON bipolar dendrite that had been closed in darkness by tonic activation of the mGluR6 cascade (Stockton and Slaughter, 1989; Nawy and Jahr, 1990; Shiells and Falk, 1990; Yamashita and Wässle, 1991; de la Villa et al., 1995; Euler et al., 1996). Thus, absence of the b-wave reflects loss of function in ON bipolar cells. Consistent with this, a mouse lacking the mGluR6 receptor also lacks the b-wave (Masu et al., 1995).

Failure of the $\mathrm{ON}$ response in the $\mathrm{G} \alpha_{\mathrm{o}}-/-$ mouse cannot be attributed to a gross deficit in retinal organization: (1) rods and cones respond normally (a-wave); (2) rod and cone synaptic terminals show normal ultrastructure (ribbons, vesicles, triad, etc.); (3) mGluR6 is expressed at the ON bipolar dendritic tip; and (4) ON bipolar cells show normal morphology and spatial density. It is possible that lack of $\mathrm{G} \alpha_{\mathrm{o}}$ affects expression of other proteins whose importance is currently unknown. However, it is more likely that the b-wave is impaired because $G_{0}$ crucially links mGluR6 to an effector that closes the cation channel. 

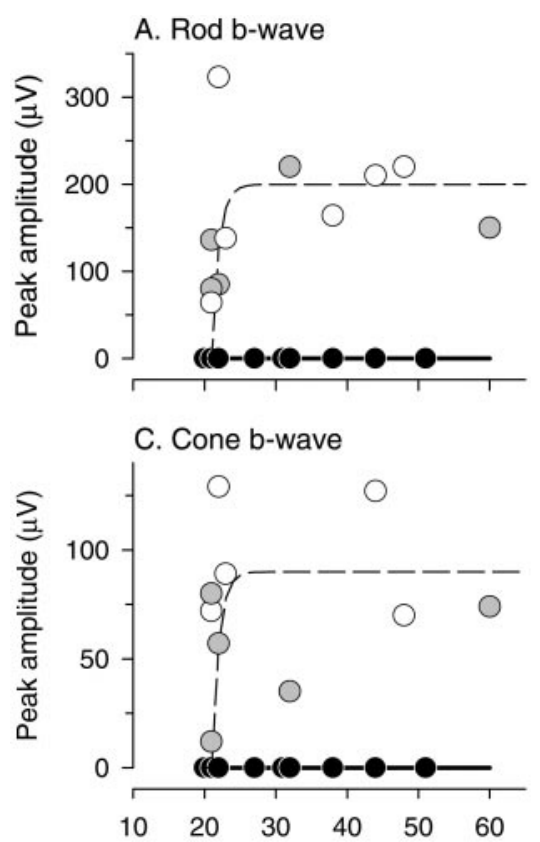
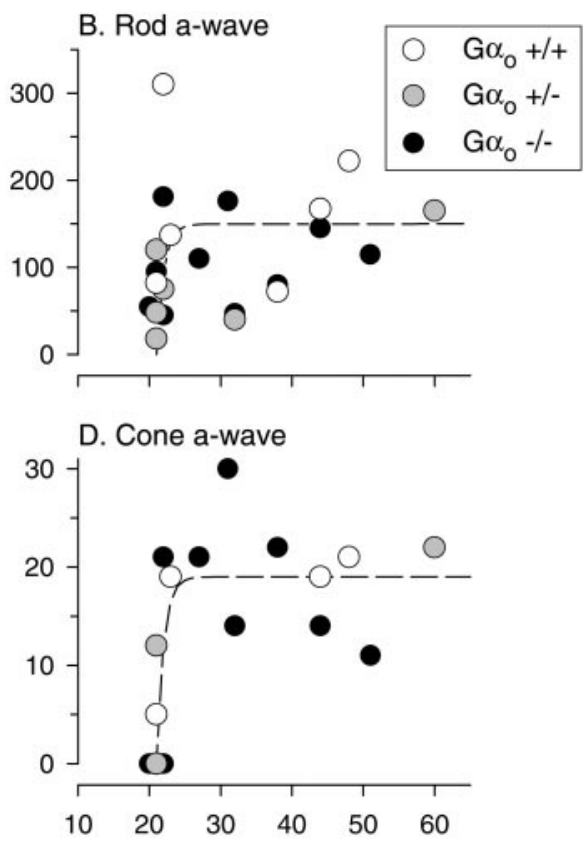

Age of mouse (days)

Figure 5. ON components of the ERG remain absent from $\mathrm{G} \alpha_{\mathrm{o}}-/-$ mice during development. The peak amplitude of the ERG a- and b-waves is variable because of variable contact with the electrode and because of rapid growth between P21 and P30. However, at all ages, the rod- and cone-driven b-waves were missing from the $\mathrm{G} \alpha_{\mathrm{o}}-/-$ mouse.
This conclusion is further supported by a considerable body of circumstantial evidence: (1) G $\alpha_{\mathrm{o}}$ colocalizes with mGluR6 in the dendritic tips of all ON bipolar types (Vardi et al., 1993, 2000; Vardi and Morigiwa, 1997; Vardi, 1998); (2) purified mGluR6 stimulated by its specific agonist, L-2-amino-4-phosphonobutyrate (L-AP-4) activates $\mathrm{G} \alpha_{\mathrm{o}}$ 18-fold more strongly than $\mathrm{G}_{\mathrm{t}}$ (transducin) (Weng et al., 1998); (3) L-AP-4 in a retinal homogenate suppresses ADP-ribosylation of a G-protein by pertussis toxin but not cholera toxin (Kikkawa et al., 1993), consistent with the sensitivity of $G_{0}$ to pertussis but not cholera toxin (Gilman, 1987); and (4) dialysis of $\mathrm{G} \alpha_{\mathrm{o}}$ or antibody to $\mathrm{G} \alpha_{\mathrm{o}}$ into $\mathrm{ON}$ bipolar cells reduces the response to glutamate (Nawy, 1999).

\section{$\mathbf{G} \boldsymbol{\alpha}_{\mathrm{o}}$-mediated cascades are poorly understood}

$\mathrm{G}_{\mathrm{o}}$ is the most abundant G-protein in the brain (Sternweis and Robishaw, 1984; Huff et al., 1985; Terashima et al., 1987; Asano et al., 1988; Li et al., 2000), and it appears to be involved in a large repertoire of signal transduction cascades. For example, $\mathrm{G}_{\mathrm{o}}$ regulates several types of voltage-gated $\mathrm{Ca}^{2+}$ channels (Kleuss et al., 1991; Valenzuela et al., 1997; Jiang et al., 1998), $\mathrm{K}^{+}$channels (VanDongen et al., 1988), a cGMP-dependent channel (in scallop ciliary photoreceptors; Kojima et al., 1997), possibly a cAMPdependent channel (in vomeronasal organ; Berghard and Buck, 1996), and a variety of serotonin-controlled behaviors in Caenorhabditis elegans (Mendel et al., 1995; Ségalat et al., 1995; Nurrish et al., 1999). In cases where $\mathrm{G}_{\mathrm{o}}$ gates the $\mathrm{N}$-type $\mathrm{Ca}^{2+}$ channel, the $\mathrm{G} \beta \gamma$ of $\mathrm{G}_{\mathrm{o}}$ complex directly binds to the $\alpha$ subunit of the channel (Dolphin, 1998), but this cannot account for the diverse effects of $\mathrm{G}_{\mathrm{o}}$, so there are probably other mechanisms.

Initially the G-protein of the $\mathrm{ON}$ bipolar cell was thought to activate a cGMP phosphodiesterase (Nawy and Jahr, 1990; Shiells and Falk, 1990). However, recent experiments using a nonhydrolyzable analog of cGMP, or various concentrations of glutamate plus phosphodiesterase inhibitor, failed to prevent glutamate from closing the channel. This suggested that the channel might be gated by something other than cGMP (Nawy, 1999). Conceivably, because the $\beta \gamma$ subunits of $\mathrm{G}_{\mathrm{o}}$ can interact directly with Q- and $\mathrm{N}$-type voltage-gated calcium channels, these subunits could also act on the ON bipolar cell cation channel. However, to the contrary, dialyzing the $\alpha$ subunit of $\mathrm{G}_{\mathrm{o}}$ into the $\mathrm{ON}$ bipolar cell mimics the effect of activated mGluR6, i.e., the cell hyperpolarizes (Nawy, 1999). If the $G \beta \gamma$ subunits served as linkers, dialyzing $\mathrm{G} \alpha_{\mathrm{o}}$ should have bound the $\mathrm{G} \beta \gamma$ subunits, prevented their activation, and thus depolarized the cell. In contrast, if the dialyzed free $\mathrm{G} \alpha_{\mathrm{o}}$ subunit were activated by GTP, it would mimic mGluR6. These experiments seem to rule out the $\beta \gamma$ subunits and support a role for $\mathrm{G} \alpha_{\mathrm{o}}$.

The targets of $\mathrm{G} \alpha_{\mathrm{o}}$ remain obscure, and this seems astonishing given that $G_{o}$ is the most abundant protein in the brain. However, the present study establishing a firm requirement for $G_{o}$ for signal transmission at a specific synapse may be an important step toward identifying the downstream targets in ON bipolar cells and in other parts of the nervous system.

\section{REFERENCES}

Asano T, Semba R, Kamiya N, Ogasawara N, Kato K (1988) G binding protein: immunochemical and immunohistochemical localization in the rat. J Neurochem 50:1164-1169.

Berghard A, Buck LB (1996) Sensory transduction in vomeronasal neurons: evidence for $\mathrm{G} \alpha \mathrm{O}, \mathrm{G} \alpha \mathrm{i} 2$, and adenylyl cyclase II as major components of a pheromone signaling cascade. J Neurosci 16:909-918.

Breton ME, Schueller AW, Lamb TD, Pugh Jr EN (1994) Analysis of ERG a-wave amplification and kinetics in terms of the G-protein cascade of phototransduction. Invest Ophthalmol Vis Sci 35:295-309.

Carlson KE, Brass LF, Manning DR (1989) Thrombin and phorbol esters cause the selective phosphorylation of a G-protein other than $G_{i}$ in human platelets. J Biol Chem 264:13298-13305.

Cohen E, Sterling P (1990) Convergence and divergence of cones onto bipolar cells in the central area of cat retina. Philos Trans R Soc Lond B Biol Sci 330:323-328.

de la Villa P, Kurahashi T, Kaneko A (1995) L-glutamate-induced responses and cGMP-activated channels in three subtypes of retinal bipolar cells dissociated from the cat. J Neurosci 15:3571-3582.

Dolphin AC (1998) Mechanisms of modulation of voltage-dependent calcium channels by G-proteins. J Physiol (Lond) 506:3-11.

Euler T, Wässle H (1995) Immunocytochemical identification of cone bipolar cells in the rat retina. J Comp Neurol 361:461-478.

Euler T, Schneider H, Wässle H (1996) Glutamate responses of bipolar cells in a slice preparation of the rat retina. J Neurosci 16:2934-2944.

Gilman AG (1987) G proteins: transducers of receptor-generated signals. Annu Rev Biochem 56:615-649.

Green DG, Kapousta-Bruneau NV (1999) A dissection of the electroretinogram from the isolated rat retina with microelectrodes and drugs. Vis Neurosci 16:727-741.

Greif GJ, Sodickson DL, Bean BP, Neer EJ, Mende U (2000) Altered regulation of potassium and calcium channels by GABA(B) and adenosine receptors in hippocampal neurons from mice lacking Galpha(o). J Neurophysiol 83:1010-1018.

Hagins WA, Penn RD, Yoshikami Y (1970) Dark current and photocurrent in retinal rods. Biophys $\mathrm{J}$ 10:380-412.

Hood DC, Birch DG (1993) Human cone receptor activity: the leading edge of the a-wave and models of receptor activity. Vis Neurosci 10:857-871.

Huff RM, Axton JM, Neer EJ (1985) Physical and immunological charac- 
terization of a guanine nucleotide-binding protein purified from bovine cerebral cortex. J Biol Chem 260:10864-10871.

Jeon C-J, Strettoi E, Masland RH (1998) The major cell populations of the mouse retina. J Neurosci 18:8936-8946.

Jiang M, Gold MS, Boulay G, Spicher K, Peyton M, Brabet P, Srinivasan Y, Rudolph U, Ellison G, Birnbaumer L (1998) Multiple neurological abnormalities in mice deficient in the $G$ protein $G_{0}$. Proc Natl Acad Sci USA 95:3269-3274.

Kikkawa S, Nakagawa M, Iwasa T, Kaneko A, Tusda M (1993) GTPbinding protein couples with metabotropic glutamate receptor in bovine retinal ON-bipolar cell. Biochem Biophys Res Commun 195:374-379.

Kleuss C, Hescheler J, Ewel C, Rosenthal W, Schultz G, Wittig B (1991) Assignment of G-protein subtypes to specific receptors inducing inhibition of calcium currents. Nature 353:43-48.

Kojima D, Terakita A, Ishikawa T, Tsukahara Y, Maeda A, Shichida Y (1997) A novel $G_{\mathrm{o}}$-mediated phototransduction cascade in scallop visual cells. J Biol Chem 272:22979-22982.

Law SF, Manning D, Reisine T (1991) Identification of subunits of GTP binding proteins coupled to somatostatin receptors. J Biol Chem 266:17885-17897.

Li X, Mumby S, Greenwood A, Jope R (1995) Pertussis toxin-sensitive G-protein $\alpha$-subunits: production of monoclonal antibodies and detection of differential increases upon differentiation of PC12 and LA-N-5 cells. J Neurochem 64:1107-1117.

Li Y, Mende U, Lewis C, Neer EJ (2000) Maintenance of cellular levels of G-proteins: different efficiencies of alpha s and alpha o synthesis in GH3 cells. Biochem J 318:1071-1077.

Lyubarsky AL, Pugh Jr EN (1996) Recovery phase of the murine rod photoresponse reconstructed from electroretinographic recordings. J Neurosci 16:563-571.

Lyubarsky AL, Falsini B, Pennesi ME, Valentini P, Pugh Jr EN (1999) UV- and midwave-sensitive cone-driven retinal responses of the mouse: a possible phenotype for coexpression of cone photopigments. J Neurosci 19:442-455.

Lyubarsky AL, Chen C-K, Simon MI, Pugh Jr EN (2000) Mice lacking G-protein receptor kinase 1 have profoundly slowed recovery of conedriven retinal responses. J Neurosci 20:2209-2217.

Martin PR, Grünert U (1992) Spatial density and immunoreactivity of bipolar cells in the Macaque monkey retina. J Comp Neurol 323:269-287.

Masu M, Iwakabe H, Tagawa Y, Miyoshi T, Yamashita M, Fukuda Y, Sasaki H, Hiroi K, Nakamura Y, Shigemoto R (1995) Specific deficit on the ON response in visual transmission by targeted disruption of the mGluR6 gene. Cell 80:757-765.

Mendel JE, Korswagen HC, Liu KS, Hajdu-Cronin YM, Simon MI, Plasterk RHA, Sternberg PW (1995) Participation of the protein $\mathrm{G}_{\mathrm{o}}$ in multiple aspects of behavior in C. elegans. Science 267:1652-1655.

Nakajima Y, Iwakabe H, Akazawa C, Nawa H, Shigemoto R, Mizuno N, Nakanishi S (1993) Molecular characterization of a novel retinal metabotropic glutamate receptor mGluR6 with a high agonist selectivity for L-2-amino-4-phosphonobutyrate. J Biol Chem 268:11868-11873.

Nawy S (1999) The metabotropic receptor mGluR6 may signal through $\mathrm{G}_{\mathrm{o}}$, but not phosphodiesterase, in retinal bipolar cells. J Neurosci 19:2938-2944.

Nawy S, Jahr CE (1990) Suppression by glutamate of cGMP-activated conductance in retinal bipolar cells. Nature 346:269-271.

Nomura A, Shigemoto R, Nakamura Y, Okamoto N, Mizuno N, Nakanishi S (1994) Developmentally-regulated postsynaptic localization of a metabotropic glutamate-receptor in rat rod bipolar cells. Cell 77:361-369.

Nurrish S, Ségalat L, Kaplan JM (1999) Serotonin inhibition of synaptic transmission: $\mathrm{G} \alpha_{\mathrm{o}}$ decreases the abundance of UNC-13 at release sites. Neuron 24:231-242.

Pugh Jr EN, Falsini B, Lyubarsky A (1998) The origin of the major rodand cone-driven components of the rodent electroretinogram and the effect of age and light-rearing history on the magnitude of these components. In: Photostasis and related phenomena (Williams T, Thistle A, eds), pp 93-128. New York: Plenum.

Robson JG, Frishman LJ (1995) Response linearity and kinetics of the cat retina: the bipolar cell component of the dark-adapted electroretinogram. Vis Neurosci 12:837-850.

Robson JG, Frishman LJ (1999) Dissecting the dark-adapted electroretinogram. Doc Ophthalmol 95:187-215.

Ségalat L, Elkes DA, Kaplan JM (1995) Modulation of serotonincontrolled behaviors by $\mathrm{G}_{\mathrm{o}}$ in Caenorhabditis elegans. Science 267:1648-1651.

Shiells RA, Falk G (1990) Glutamate receptors of rod bipolar cells are linked to a cyclic GMP cascade via a G-protein. Proc R Soc Lond B Biol Sci 242:91-94.

Shiells RA, Falk G (1999) Contribution of rod, on-bipolar, and horizontal cell light responses to the ERG of dogfish retina. Vis Neurosci 16:503-511.

Sterling P, Freed MA, Smith RG (1988) Architecture of the rod and cone circuits to the On-beta ganglion cell. J Neurosci 8:623-642.

Sternweis PC, Robishaw JD (1984) Isolation of two proteins with high affinity for guanine nucleotides from membranes of bovine brain. J Biol Chem 259:13806-13813.

Stockton RA, Slaughter MM (1989) B-wave of the electroretinogram. A reflection of ON bipolar cell activity. J Gen Physiol 93:101-122.

Strettoi E, Masland R (1995) The organization of the inner nuclear layer of the rabbit retina. J Neurosci 15:875-888.

Terashima T, Katada T, Okada E, Ui M, Inoue Y (1987) Light microscopy of GTP-binding protein $\left(\mathrm{G}_{\mathrm{o}}\right)$ immunoreactivity within the retina of different vertebrates. Brain Res 436:384-389.

Valenzuela D, Han X, Mende U, Fankhauser C, Mashimo H, Huang P,

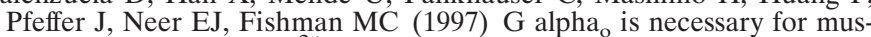
carinic regulation of $\mathrm{Ca}^{2+}$ channels in mouse heart. Proc Natl Acad Sci USA 94:1727-1732.

VanDongen AM, Codina J, Olate J, Mattera R, Joho R, Birnbaumer L, Brown AM (1988) Newly identified brain potassium channels gated by the guanine nucleotide binding protein $\mathrm{G}_{\mathrm{o}}$. Science 242:1433-1437.

Vardi N (1998) Alpha subunit of $G_{0}$ localizes in the dendritic tips of ON bipolar cells. J Comp Neurol 395:43-52.

Vardi N, Morigiwa K (1997) ON cone bipolar cells in rat express the metabotropic receptor mGluR6. Vis Neurosci 14:789-794.

Vardi N, Matesic DF, Manning DR, Liebman PA, Sterling P (1993) Identification of a G-protein in depolarizing rod bipolar cells. Vis Neurosci 10:473-478.

Vardi N, Duvoisin RM, Wu G, Sterling P (2000) Localization of mGluR6 to dendrites of $\mathrm{ON}$ bipolar cells in primate retina. J Comp Neurol 423:402-412.

Wässle H, Grünert U, Cook NJ, Molday RS (1992) The cGMP-gated channel of rod outer segments is not localized in bipolar cells of the mammalian retina. Neurosci Lett 134:199-202.

Weng K, Lu C-C, Daggett LP, Kuhn R, Flor PJ, Johnson ED, Robinson PR (1998) Functional coupling of a human retinal metabotropic glutamate receptor (hmGluR6) to bovine rod transducin and rat $\mathrm{G}_{\mathrm{o}}$ in an in vitro reconstruction system. J Biol Chem 272:33100-33104.

Yamashita M, Wässle H (1991) Responses of rod bipolar cells isolated from the rat retina to the glutamate agonist 2-amino-4-phosphonobutyric acid (APB). J Neurosci 11:2372-2382. 